\title{
South African developed meat type goats: A forgotten animal genetic resource?
}

\author{
A.Pieters ${ }^{1}$, E. van Marle-Köster ${ }^{1}$, C. Visser ${ }^{1}, \mathcal{E}$ A. Kotze $^{2}$ \\ ${ }^{1}$ Department of Animal \& Wildlife Sciences, University of Pretoria, Pretoria 0002, South Africa \\ ${ }^{2}$ National Zoological Gardens, Pretoria 0002, South Africa
}

\section{Summary}

There are mainly three locally developed meat type goat breeds in South Africa namely the South African Boer goat, the Savanna and the Kalahari Red. In order to maintain the characteristics of these breeds and to ensure that their unique traits are not lost through continuous selection and cross-breeding, it has become important to revisit current breed standards and introduce genetic characterization to obtain genetic diversity parameters. Both the Boer goat and Savanna breeds have established breeders associations while a breeders club was founded for the Kalahari Red goats. These associations have set breed standards and the breeds' morphometric traits have recently been described. The differences in morphometric traits among the breeds are fairly insignificant. Preliminary data on genetic diversity report heterozygosity values above $50 \%$ for each of the three breeds and they can be distinguished as separate breeds based on genotyping results with eighteen ISAG recommended microsatellite markers. There is however a need for a genetic characterization of both meat type and indigenous goats to ensure sufficient diversity within the breeds for long term conservation of the unique genetic resource.

\section{Resumé}

Il y a en gros trois races de chèvres à viande développées en Afrique du Sud, à savoir la chèvre Boer sud-africaine, la Savanna et la Kalahari Rouge. Afin de conserver les caractéristiques de ces races et de faire en sorte que leurs traits uniques ne se perdent pas au cours des sélections et croisements continus, il est devenu nécessaire de revoir les normes des races actuelles et d'introduire des caractéristiques génétiques pour obtenir des paramètres de diversité génétique. La race de chèvre Boer et la Savanna ont des associations d'éleveurs établies, tandis qu'un club d'éleveurs a été créé pour les Kalahari Rouge. Ces associations ont des normes raciales bien définies et les traits morpho-métriques des races ont été décrits récemment. Les différences dans les traits morpho-métriques des races sont négligeables. Les données préliminaires sur la diversité génétique révèlent des valeurs hétérozygotes de plus de $50 \%$ pour chacune des trois races et elles peuvent être distinguées comme des races séparées en se basant sur les résultats génotypiques avec dix-huit marqueurs microsatellites recommandés par l'ISAG. Cependant, il faut faire une caractérisation génétique des deux types de viande et des chèvres indigènes pour garantir une diversité suffisante dans les races afin de conserver à long terme cette unique ressource génétique.

\section{Resumen}

Existen mayormente tres razas de cabras de carne en Sud Africa, la cabra Boer sudafricana, la Savanna y la Kalahari Roja. Con el fin de conservar las características de estas razas y conseguir que sus rasgos únicos no se pierdan a lo largo de selecciones y cruces continuos, se ha hecho necesario revisar las normas de las razas actuales e introducir características genéticas para obtener parámetros de diversidad genética. Las razas de cabra Boer y Savanna poseen asociaciones de ganaderos, mientras que un club de ganaderos ha sido creado para la Kalahari Roja. Estas asociaciones tienen normas bien definidas para las razas y los rasgos morfométricos han sido descritos recientemente. Las diferencias en los rasgos morfométricos entre las razas no son importantes. Los datos preliminares sobre la diversidad genética revelan valores de heterocigosis de más del $50 \%$ para cada una de las tres razas y pueden diferenciarse como razas separadas en base a los resultados genotípicos con dieciocho marcadores microsatelitares recomendados por ISAG. Sin 
embargo, hay que hacer una caracterización genética de dos tipos de carne y de cabras indígenas para garantizar una diversidad suficiente entre las razas con el fin de conservar a largo plazo este recurso genético único.

Key words: Meat type, Phenotypic, Genetic characteristics, Utilization, Conservation.

\section{Introduction}

South Africa has a goat population of approximately 6.6 million of which $64 \%$ are kept and / or commercially farmed within the rural areas (Coetzee, 1998). The primary goat breeds consist of Angora for mohair production, three meat type goat breeds namely the South African Boer goat, the Savanna and the Kalahari Red and a number of indigenous types that are primarily classified according to the geographical area in which they reside. Apart from the Angora goats, these breeds are all believed to originate from indigenous types, which had migrated to Southern Africa by 2500 BC, due to increasing desertification of the southern regions of the Sahara (Maree and Plug, 1993). The local Khoisan shepherds travelled southwards from Northern Botswana down to the Orange River and later followed two additional routes to reach the Southern and Western Cape. One of the earliest references to the presence of goats in the Northern Cape was made by the missionary, J. Burrow, who described the goats kept by the local people as "handsome goats, speckled like the leopard" (Campbell, 2003). These goats, also referred to as 'skilder' goats or speckled goats, were most likely the resource, which led to the development of the current meat type goats.

These locally developed breeds have been subjected to artificial selection for improved production and growth. Although this has led to improved performance in the breeds, the question arises if specific genetic characteristics could be compromised by continuous selection for improvement of growth and meat characteristics. Often these breeds and our indigenous types are marketed as having special adaptive characteristics; local types often survive tick borne diseases better than commercial types (Malan, 2000; Erasmus, 2000).

According to some authors, true indigenous goat breeds in South Africa have been virtually cross-bred to extinction due to the development of the meat type goats such as the Boer goat (Campbell,
1995). Some researchers and farmers believe that the pure 'unimproved' indigenous goats possess important economic traits (including viability, good mothering ability, disease resistance and resistance against ticks), which should not be disregarded (Campbell, 1995; Van der Walt, 200, personal communication).

Recently a strategy for the conservation and utilization of South African genetic animal resources, including goat genetic resources, has been formulated. This policy aims at facilitating poverty alleviation through the strategic management of genetic resources, thereby improving the livelihoods of farmers and rural communities. The characterization and evaluation of genetic resources is one of the proposed ways in which this goal could be attained (National Department of Agriculture: Genetic resource management, 2008).

In order to maintain the characteristics of these locally developed breeds and ensure that their unique traits are not lost through continuous selection and cross-breeding, it has become important to revisit current breed standards and introduce genetic characterization to obtain genetic diversity parameters.

The objective of this paper was therefore to review the potential of locally developed meat type goats as a genetic resource with reference to their phenotypic and genetic characteristics.

\section{Material and Methods}

\section{Phenotypic and genetic characteristics}

Goats are well adapted to the drier western region of South Africa and northern regions where bush encroachment is a problem (Figure 1). It is also in these areas where the Boer, Kalahari Red and Savanna goats are primarily farmed in commercial systems for meat production.

Of the three breeds the Boer goat has the longest official history with the formulation of breed standards in 1959 when the South African Boer Goat Association was founded (Campbell, 2003). The breed standards specify a red head and the Boer goat replaced many unimproved local strains of varying colours with the strict selection for a white body and red head depicted in figure 2 . Boer goats are large, long-legged goats with short, soft hair and long ears. These goats have a sturdy head with a compressed nose and strong horns that have a gradual backward curve. They have fleshy, 


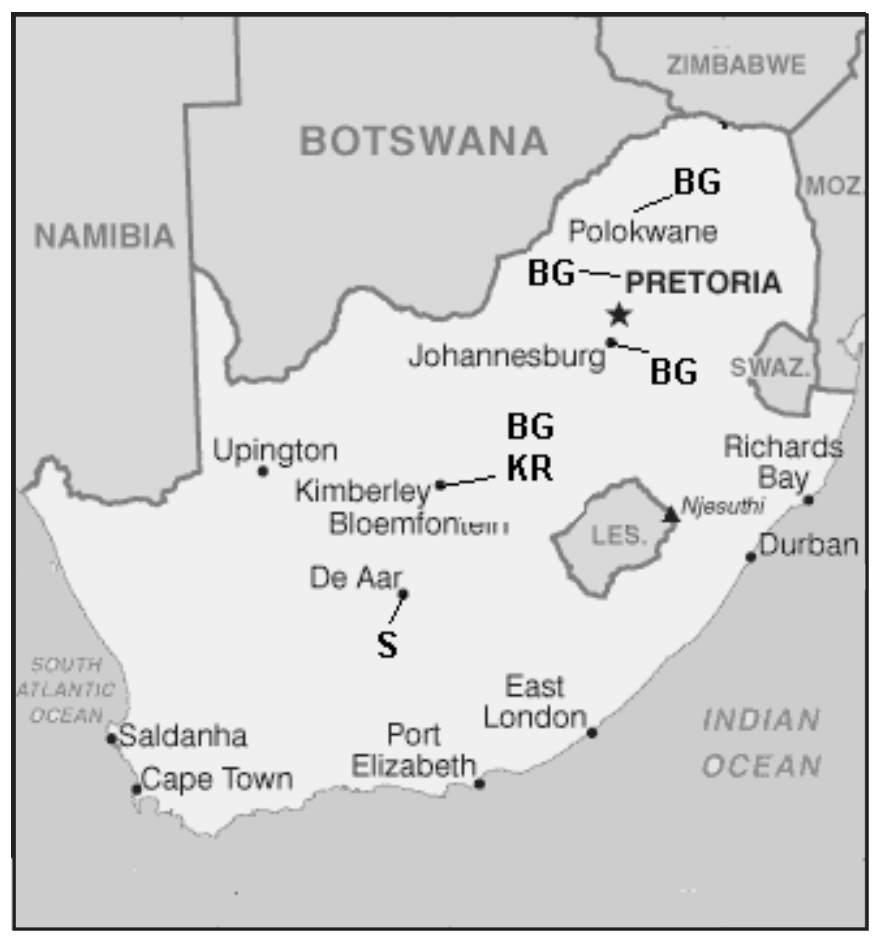

Figure 1. Distribution of the meat type goat breeds.

well-developed broad briskets, well-sprung ribs, broad backs and muscular legs (Sambraus, 1992) and well fleshed buttocks and thighs. The mature Boer goat buck weighs between 110 and $135 \mathrm{~kg}$ and does weigh between 90 and $100 \mathrm{~kg}$ (Malan, 2000). The Boer goat does are known for their good mothering ability (Figure 2) and can kid every seven to eight months. They have an exceptional ability to resist and survive diseases such as blue tongue, prussic acid poisoning and, to a lesser extent, enterotoxaemia (Malan, 2000; Erasmus, 2000).

The Kalahari Red (Figure 3) is believed to have originated from two lines, namely a line of red-headed Boer goat and another of the 'unimproved' local goats in South Africa (Campbell, 2003). The Kalahari Red have a distinct red colour, shown in Figure 3, and are often used in crossbreeding to produce goats with a uniform, solid, red colour. They are fully pigmented and are able to endure heat and intense sunlight, as their dark coats and long ears provide good heat resistance (http://studbook.co.za). The breed has excellent walking ability and good mothering ability and they can kid three times in two years.

The white Savanna goat (Figure 4), also known as the white Boer goat, was developed from indigenous goats of Southern Africa during the past few decades (Campbell, 2003). The breed standards allow limited red, blue and black hairs (http://ourfarmsite.com/web/goats/goatsavannal breedstandards.html). The Savanna goat has short kempy white hair with a black skin, horns, nose and udder, and during the winter the goats develop extra fluffy cashmere hair for protection. Their heads are fairly long and slightly curved with big, oval shaped ears. The forequarter is well muscled and of medium width, with a reasonably long neck for easy browsing. Does have excellent mothering traits and about $22 \%$ of their offspring are born as twins and triplets, under extensive conditions. The Savanna and Kalahari Red goats have been recognised in South Africa as official breeds since 1993 and 1990, respectively.

\section{Morphometric traits}

Morphometric data was collected from goats with an average age of 12 months in a recent study in 2007. The measurements taken and their full descriptions are reported in table 1 . Goats were sampled from a number of stud herds in order to be representative of the different breeds (sample collection are indicated in figure 1) and linear traits were measured for a total of 42 Boer goats, 47 Kalahari Reds and 49 Savanna goats. The goats 


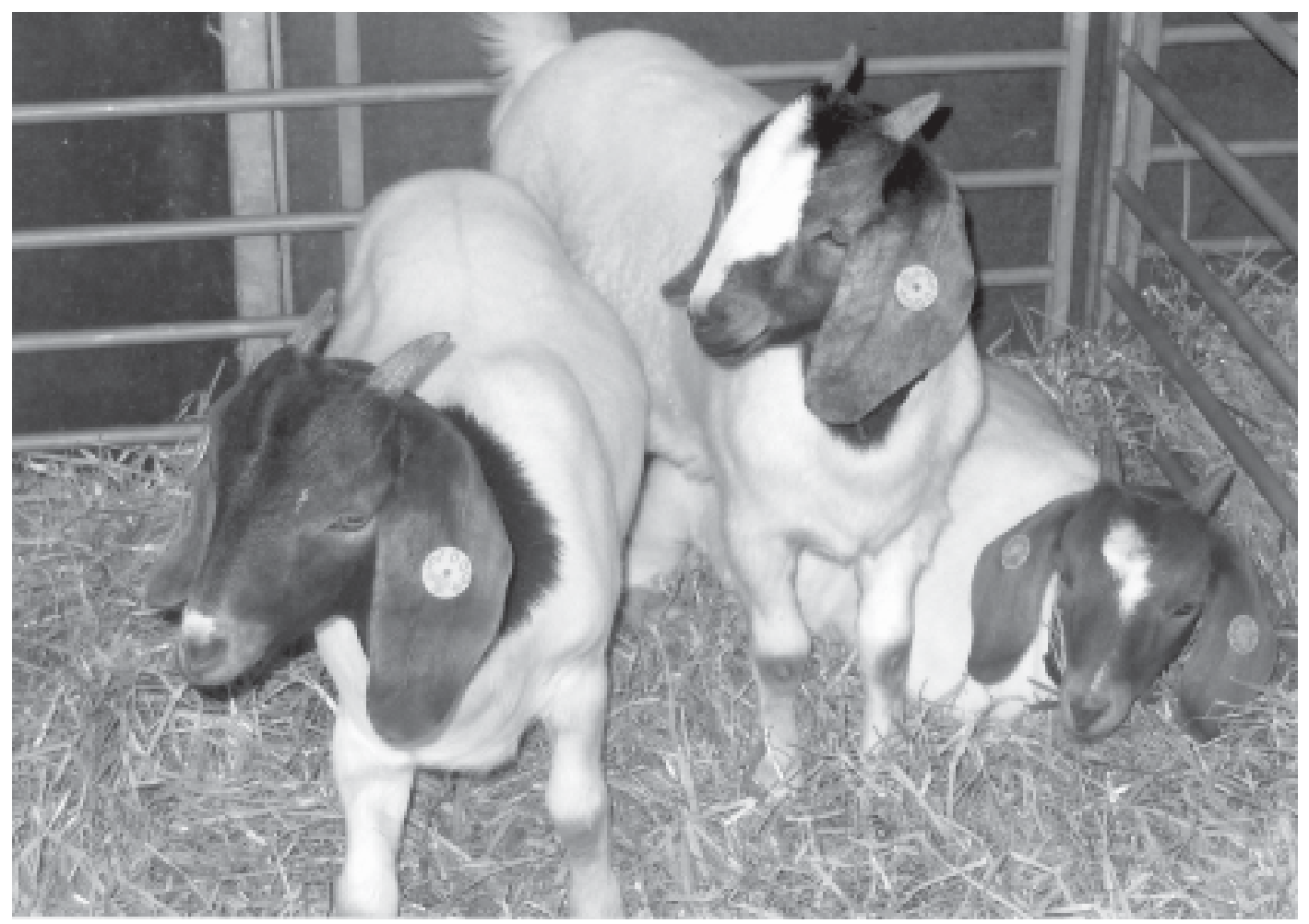

Figure 2. Typic South African Boer goats with a white body and red head and neck.

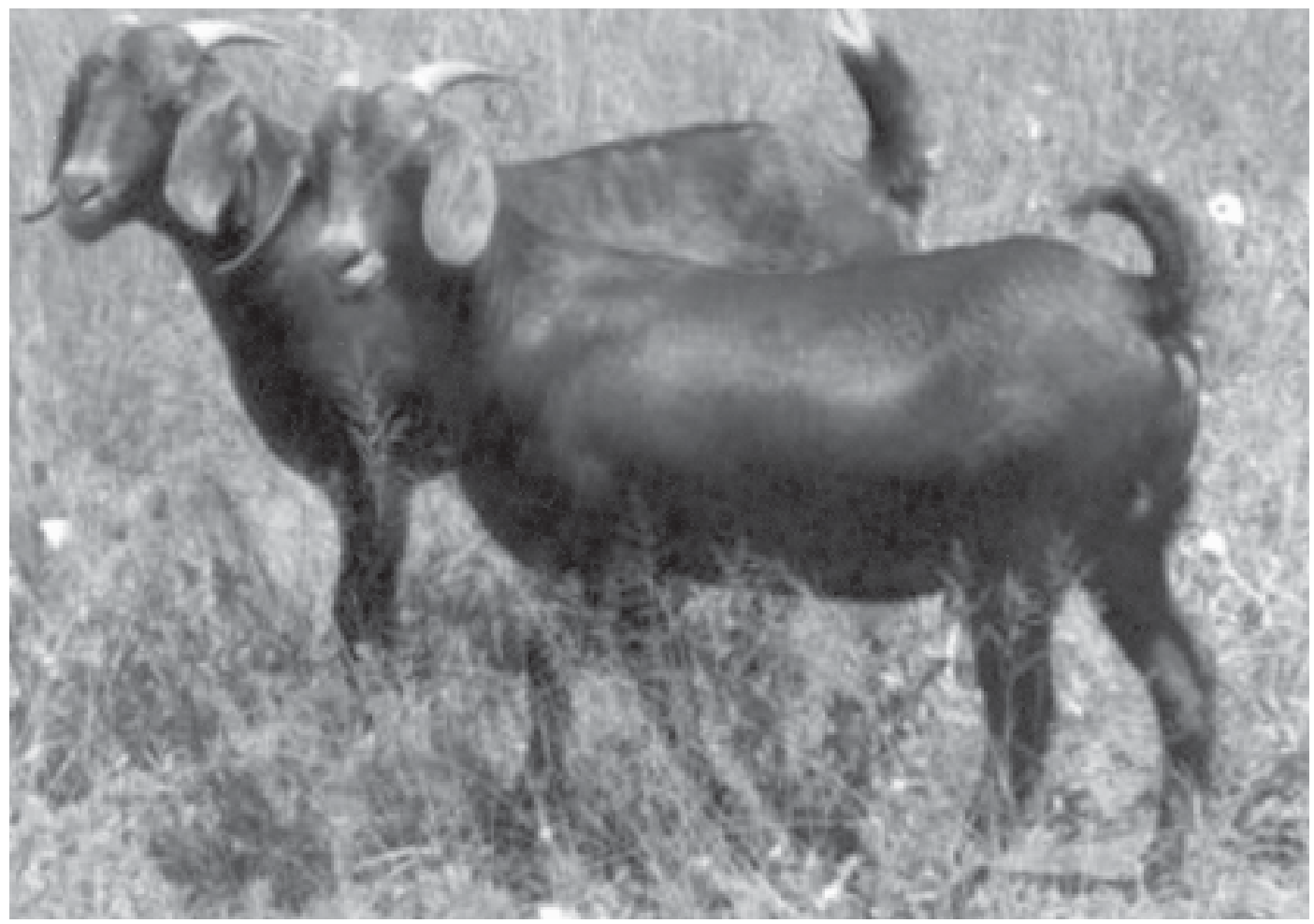

Figure 3. Kalahari Red goats with a uniform red coat colour. 


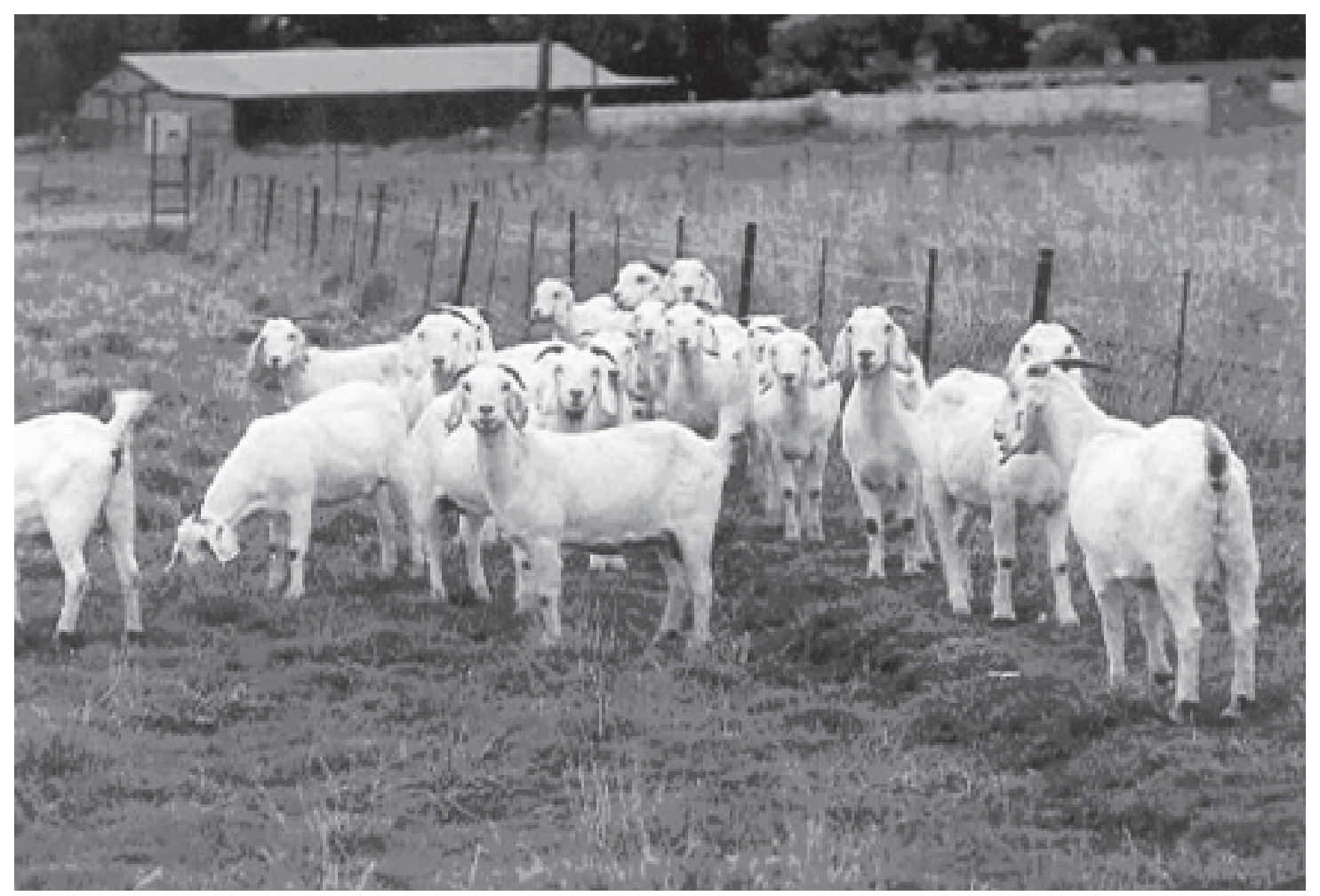

Figure 4. Typic flock of white Savanna goats.

Table 1. Description of morphometric measurements.

\begin{tabular}{ll}
\hline Measurement $^{1}$ & Description \\
\hline Height (H) & Vertical distance to the ground, measured behind the whithers \\
Length (L) & From the anterior shoulder point to the posterior extremity of the pin bone \\
Loin width (LW) & Measured just in front of the haunches (os coxea) \\
Depth (D) & Between Corpus Sterni and the point between the shoulder blades \\
Heart girth (HG) & Measured just behind the shoulder \\
Hock length (HL) & From the front to back margin \\
Head width (HW) & Distance between eyes \\
Head length (HL) & Length of head \\
Neck circumference (N) & Circumference \\
Tail length (TL) & From the tail base to tip \\
Pelvic width (PW), & Between pelvis bones \\
Pelvic length (PL) & From pelvic bone to os coxea \\
\hline
\end{tabular}

${ }^{1} \mathrm{~A}$ tape measure and measuring-rod were used to obtain various body measurements (in $\mathrm{cm}$ ).

were also classified according to qualitative characteristics including beardedness (absence or presence of beard), incidence of horns (horned or polled) and coat colour. A General Linear Model (GLM) procedure of SAS (1992) was applied for analyses of the different traits measured.

\section{Genetic characterization}

A genetic characterization of the local meat type breeds has been undertaken by the Department of Animal and Wildlife Sciences at the University of Pretoria. The blood samples were collected from the 
same areas as described for the phenotypic measurements. For the genetic characterization additional flocks were included to ensure that unrelated samples are collected as far as possible. The Boer goats (62) represented three areas, two different flocks from the Northern Cape (31), and two experimental populations of Boer goats (31 Eastern Cape and 17 Limpopo provinces) not subjected to selection. The 60 blood samples for the Kalahari Red were collected from six flocks and the 55 Savannah samples from two different flocks in the Northern Cape. Eighteen microsatellite markers were selected from a panel of markers recommended by the International Society for Animal Genetics (ISAG) for application in diversity studies. These markers were selected based on the degree of polymorphism and genome coverage (Table 2 ) and available on web at: lprdad.fao.org/cgi-bin/ getblob.coi? sid $=4 d 60 c 0 a 342 d 8413 c 49 a c c$ b8c1837ebf5,50005880 and background at www.isag.org.uk/ISAG/all/ ISAG2004_ISAGFAO_AGAGD.pdf;ftp://ftp.fao.org/

Table 2. Microsatellite marker information applied in this study.

\begin{tabular}{|c|c|c|c|c|}
\hline $\begin{array}{l}\text { Microsatellite } \\
\text { marker }\end{array}$ & $\begin{array}{c}\text { Chromosome } \\
\text { number }\end{array}$ & $\begin{array}{c}\begin{array}{c}\text { Fluorescent } \\
\text { label }^{1}\end{array} \\
\end{array}$ & $\begin{array}{c}\text { Product } \\
\text { size range }\end{array}$ & Sequence \\
\hline \multirow[t]{2}{*}{ SRCRSP24 } & Unknown & Fam & $162-174$ & F 5'- AGC AAG AAG TGT CCA CTG ACA G-3' \\
\hline & & & & R 5' -TCT AGG TCC ATC TGT GTT ATT GC-3' \\
\hline \multirow[t]{2}{*}{ SRCRSP5 } & 21 & Tet & $171-183$ & F 5' -GGA CTC TAC CAA CTG AGC TAC AAG- 3' \\
\hline & & & & R 5 -TGA AAT GAA GCT AAA GCA ATG C-3' \\
\hline \multirow[t]{2}{*}{ SRCRSP8 } & Unknown & Tet & $210-260$ & F 5' -TGC GGT CTG GTT CTG ATT TCA C-3' \\
\hline & & & & R 5' -CCT GCA TGA GAA AGT CGA TGC TTA G- 3' \\
\hline \multirow[t]{2}{*}{ MCM527 } & 5 & Hex & $155-173$ & F 5' -GTC CAT TGC CTC AAA TCA ATT C- $3^{\prime}$ \\
\hline & & & & R 5' -AAA CCA CTT GAC TAC TCC CCA A- 3' \\
\hline \multirow[t]{2}{*}{ INRA 23} & 3 & Tet & $208-214$ & F 5' -GAG TAG AGC TAC AAG ATAA AAC TTC- $3^{\prime}$ \\
\hline & & & & R 5' -TAA CTA CAG GGT GTT AGA TGA ACT CA- 3' \\
\hline \multirow[t]{2}{*}{ BM1329 } & 6 (sheep) & Tet & $168-182$ & F 5' -TTG TTT AGG CAA GTC CAA AGT C- 3' \\
\hline & & & & R 5' - AAC ACC GCA GCT TCA TCC- 3' \\
\hline \multirow[t]{2}{*}{ OARFCB20 } & 2 & Tet & $99-125$ & F 5' - AAA TGT GTT TAA GAT TCC ATA CAG TG- $3^{\prime}$ \\
\hline & & & & R 5' - GGA AAA CCC CCA TAT ATA CCT ATA C- 3' \\
\hline \multirow[t]{2}{*}{ CRSRD247 } & 14 & Fam & $236-244$ & F 5' - GGA CTT GCC AGA ACT CTA CAA T- $3^{\prime}$ \\
\hline & & & & R 5' -CAC TGT GGT TTG TAT TCA GG- 3' \\
\hline \multirow[t]{2}{*}{ ILST087 } & 28 & Fam & $145-165$ & F 5' - AGC AGA CAT GAT GAC TCA GC- 3' \\
\hline & & & & R 5' -CTG CCT CTT TTC TTG AGA GC- 3' \\
\hline \multirow[t]{2}{*}{ SRCRSP23 } & Unknown & Fam & $83-111$ & F 5' - TGA ACG GGT AAA GAT GTG -3' \\
\hline & & & & R 5' -TGT TTT TAA TGG CTG AGT AG- $3^{\prime}$ \\
\hline \multirow[t]{2}{*}{ OARFCB11 } & 2 & Hex & $142-150$ & F 5' -GGC CTG AAC TCA CAA GTT GAT ATA TCT ATC AC- $3^{\prime}$ \\
\hline & & & & R 5' -GCA AGC AGG TTC TTT ACC ACT AGC ACC- 3' \\
\hline \multirow[t]{2}{*}{ ILST002 } & Unknown & Hex & $118-127$ & F 5' -TCT ATA CAC ATG TGC TGT GC- $3^{\prime}$ \\
\hline & & & & R 5' -CTT AGG GGT GAA GTG ACA CG- 3' \\
\hline \multirow[t]{2}{*}{ RM004 } & 15 & Tet & $138-146$ & F 5' -AG CAA AAT ATC AGC AAA CCT- $3^{\prime}$ \\
\hline & & & & R 5' -CCA CCT GGG AAG GCC TTT A- 3' \\
\hline \multirow[t]{2}{*}{ INRA63 } & 18 & Fam & $174-190$ & F 5' -ATT TGC ACA AGC TAA ATC TAA CC- $3^{\prime}$ \\
\hline & & & & R 5' -CCA CCT GGG AAG GCC TTT A- 3' \\
\hline \multirow[t]{2}{*}{ INRA006 } & 3 & Hex & $109-123$ & F 5' -AGG AAT ATC TGT ATC AAC CTC AGT C- $3^{\prime}$ \\
\hline & & & & R 5' -CTG AGC TGG GGT GGG AGC TAT AAA TA- 3' \\
\hline \multirow[t]{2}{*}{ MAF65 } & 15 & Tet & $117-127$ & F 5' - AAA GGC CAG AGT ATG CAA TTA GGA G- 3' \\
\hline & & & & R 5' - CCA CTC CTC TGA GAA TAT AAC ATG- 3' \\
\hline \multirow[t]{2}{*}{ BM1258 } & 23 & Fam & $102-106$ & F 5' -GTA TGT ATT TTT CCC ACC CTG C- $3^{\prime}$ \\
\hline & & & & R 5' - GAG TCA GAC ATG ACT GAG CCT G(AT)- 3' \\
\hline
\end{tabular}


docrep/fao/010/a1250e/annexes/

Reports\%20from\%20International\%20Organizations/ ISAG.pdf.

PCR reactions were carried out in a volume of $8.2 \mu \mathrm{l}$, containing $50 \mathrm{ng}$ target DNA, $3.48 \mu \mathrm{M}$ dNTP's, $10 \mathrm{mM}$ TrisHCl (pH =9.0), $1.5 \mathrm{mM} \mathrm{MgCl}_{2^{\prime}}$ 1.74 unit Taq Polymerase enzyme (Goldstar) and 4.54pmol of each primer (microsatellite marker). Preparation of samples was followed by thermal cycling in a Thermal Controller (Perkin Elmer) using the following program: 12 minutes at $94^{\circ} \mathrm{C}$ followed by 33 cycles consisting of $45 \mathrm{sec}$ at $94^{\circ} \mathrm{C}$, $80 \mathrm{sec}$ at $60^{\circ} \mathrm{C}, 60 \mathrm{sec}$ at $72^{\circ} \mathrm{C}$ and an extension step of $60 \mathrm{~min}$ at $72^{\circ} \mathrm{C}$. GENESCAN-350 TAMRA was used as internal standard and samples were analyzed on an automated DNA-Sequencer (ABI 377). The Genescan version 2.0 and Genotyper for MacIntosch were used to determine the fragment sizes in base pairs. Hardy Weinberg Equilibrium, heterozygosity and effective number of alleles were calculated using POPGENE 3.2 (Yeh et al., 1999) and Microsattellite Toolkit ( Park, 2001). A factorial correspondence analysis was performed to illustrate the relationship among the breeds using Genetix 4.03 (Belkhir et al., 1996).

\section{Results}

Of the goats measured $13 \%$ of the Boer goats, $23 \%$ of the Kalahari Red and $25 \%$ of the Savanna goats were bearded. Seventy five percent of all the Boer goats had white bodies with red heads, while the remaining 25\% had either speckled heads or a red spot on the body. The Kalahari Red goats were primarily red coated with a white or black spot appearing on the body of $15 \%$ of the population. Savanna goats were all white. Morphometric measurements analyzed were presented in table 3.

All the microsatellite markers tested were found to be in Hardy Weinberg Equilibrium, except for some markers in the Savanna goats.

The effective number of alleles showed little variation, from 2.9 in the Boer goat to 3.4 in the Kalahari Red goats. Preliminary heterozygosity

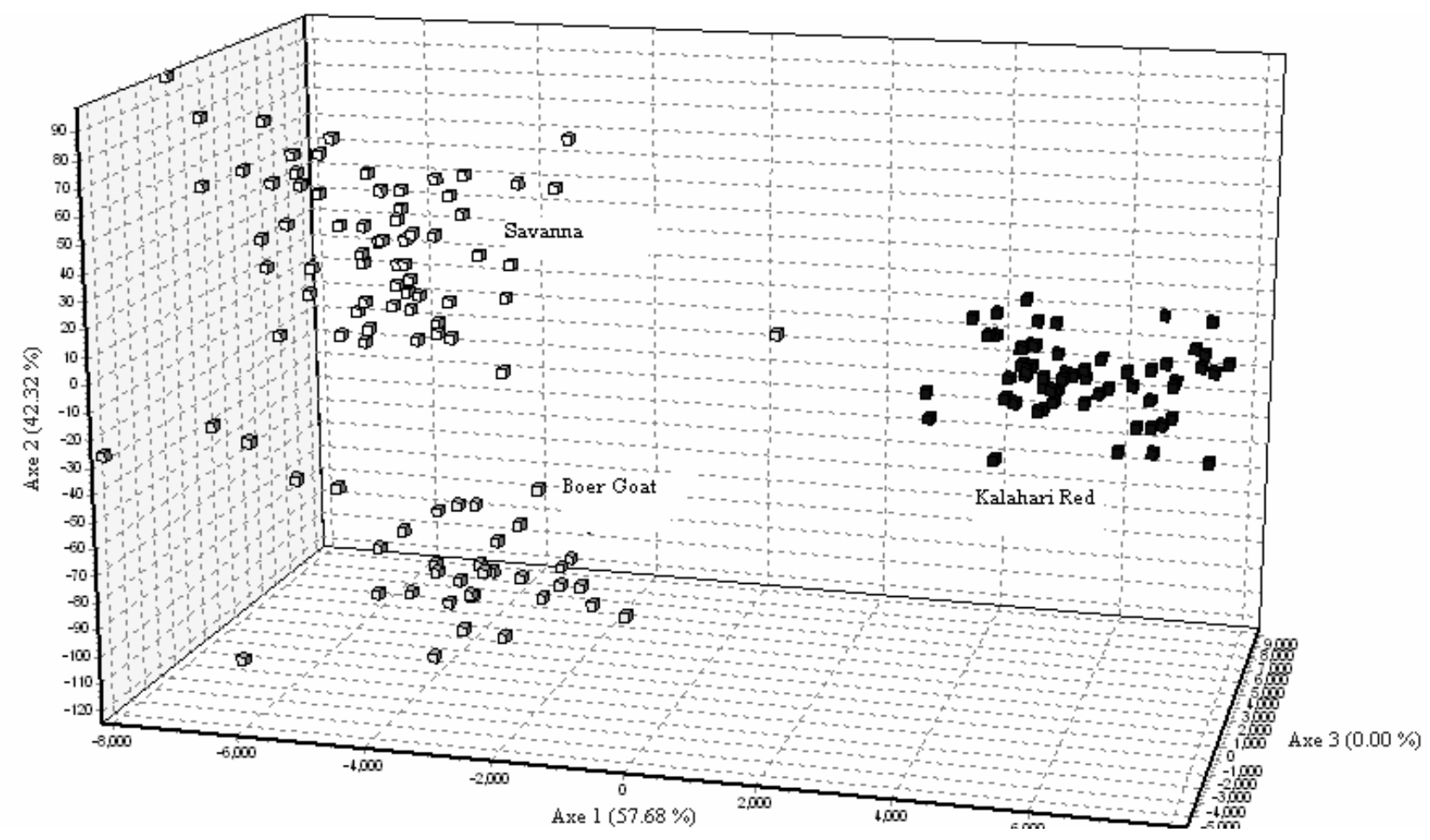

Figure 5 Assignment of individuals to the respective populations using a Factorial Correspondence Analyses. 
Table 3. Statistical description of body measurements (cm) recorded for 42 Boer goats , 47 Kalahari Red and 49 Savanna goats.

\begin{tabular}{|c|c|c|c|c|c|}
\hline \multirow[b]{2}{*}{ Trait } & \multirow[b]{2}{*}{ Breed } & \multicolumn{2}{|c|}{ Body measurements } & \multirow{2}{*}{$\begin{array}{l}\text { Least square } \\
\text { means }^{1}\end{array}$} & \multirow{2}{*}{$\begin{array}{l}\text { Standarc } \\
\text { error }( \pm)\end{array}$} \\
\hline & & Min. & Max. & & \\
\hline \multirow{3}{*}{$\begin{array}{l}\text { Height } \\
(\mathrm{H})\end{array}$} & Boer Goat & 47.0 & 67.5 & $56.5^{\mathrm{a}}$ & 0.5 \\
\hline & Kalahari Red & 49.3 & 60.2 & $54.1^{\mathrm{a}}$ & 0.5 \\
\hline & Savanna & 47.8 & 61.9 & $55.7^{\mathrm{a}}$ & 0.5 \\
\hline \multirow{3}{*}{$\begin{array}{l}\text { Length } \\
\text { (L) }\end{array}$} & Boer Goat & 55.0 & 79.5 & $68.2^{\mathrm{ab}}$ & 0.8 \\
\hline & Kalahari Red & 60.6 & 83.2 & $69.8^{\mathrm{a}}$ & 0.8 \\
\hline & Savanna & 30.0 & 71.1 & $64.9^{\mathrm{b}}$ & 0.7 \\
\hline \multirow{3}{*}{$\begin{array}{l}\text { Depth } \\
\text { (D) }\end{array}$} & Boer Goat & 22.2 & 33.0 & $26.4^{\mathrm{ab}}$ & 0.3 \\
\hline & Kalahari Red & 23.0 & 31.8 & $27.1^{\mathrm{a}}$ & 0.3 \\
\hline & Savanna & 22.4 & 29.0 & $24.9^{\mathrm{b}}$ & 0.3 \\
\hline \multirow{3}{*}{$\begin{array}{l}\text { Heart Girth } \\
\text { (HG) }\end{array}$} & Boer Goat & 78.0 & 112.0 & $90.3^{a b}$ & 1.0 \\
\hline & Kalahari Red & 65.6 & 114.0 & $95.3^{\mathrm{a}}$ & 1.0 \\
\hline & Savanna & 72.6 & 100.2 & $86.5^{\mathrm{b}}$ & 1.0 \\
\hline \multirow{3}{*}{$\begin{array}{l}\text { Hock Length } \\
\text { (HL) }\end{array}$} & Boer Goat & 16.5 & 34.0 & $28.3^{\mathrm{a}}$ & 0.5 \\
\hline & Kalahari Red & 15.2 & 36.1 & $27.7^{\mathrm{a}}$ & 0.5 \\
\hline & Savanna & 18.1 & 29.1 & $23.5^{\mathrm{b}}$ & 0.5 \\
\hline \multirow{3}{*}{$\begin{array}{l}\text { Head Width } \\
\text { (HW) }\end{array}$} & Boer Goat & 4.8 & 10.5 & $7.7^{\mathrm{a}}$ & 0.2 \\
\hline & Kalahari Red & 4.8 & 8.9 & $6.6^{\mathrm{b}}$ & 0.3 \\
\hline & Savanna & 4.2 & 7.3 & $5.6^{c}$ & 0.2 \\
\hline \multirow{3}{*}{$\begin{array}{l}\text { Head Length } \\
\text { (HL) }\end{array}$} & Boer Goat & 13.0 & 21.0 & $17.2^{\mathrm{a}}$ & 0.3 \\
\hline & Kalahari Red & 9.8 & 21.6 & $15.7 \mathrm{~b}$ & 0.2 \\
\hline & Savanna & 13.1 & 20.0 & $15.8^{\mathrm{ab}}$ & 0.2 \\
\hline \multirow{3}{*}{$\begin{array}{c}\text { Neck } \\
\text { Circumference } \\
(\mathrm{N})\end{array}$} & Boer Goat & 33.2 & 57.0 & $48.3^{\mathrm{a}}$ & 4.0 \\
\hline & Kalahari Red & 33.7 & 58.5 & $42.5^{\mathrm{ab}}$ & 3.8 \\
\hline & Savanna & 30.4 & 65.4 & $37.7^{\mathrm{ab}}$ & 3.7 \\
\hline \multirow{3}{*}{$\begin{array}{l}\text { Tail Length } \\
\text { (TL) }\end{array}$} & Boer Goat & 6.0 & 17.0 & $12.2^{\mathrm{ab}}$ & 0.3 \\
\hline & Kalahari Red & 10.4 & 19.2 & $13.2^{\mathrm{a}}$ & 0.3 \\
\hline & Savanna & 9.6 & 19.0 & $13.3^{\mathrm{a}}$ & 0.3 \\
\hline \multirow{3}{*}{$\begin{array}{l}\text { Pelvic Width } \\
\quad(P W)\end{array}$} & Boer Goat & 7.8 & 21.4 & $13.8^{\mathrm{a}}$ & 0.3 \\
\hline & Kalahari Red & 9.0 & 13.5 & $11.1^{\mathrm{b}}$ & 0.3 \\
\hline & Savanna & 8.4 & 17.7 & $11.4^{\mathrm{b}}$ & 0.3 \\
\hline \multirow{3}{*}{$\begin{array}{c}\text { Pelvic Length } \\
\text { (PL) }\end{array}$} & Boer Goat & 13.5 & 26.5 & $19.7^{\mathrm{a}}$ & 0.4 \\
\hline & Kalahari Red & 16.0 & 24.8 & $20.5^{\mathrm{a}}$ & 0.3 \\
\hline & Savanna & 16.7 & 27.4 & $19.1^{\mathrm{a}}$ & 0.3 \\
\hline \multirow{3}{*}{$\begin{array}{l}\text { Ear Length } \\
\text { (EL) }\end{array}$} & Boer Goat & 14.4 & 26.0 & $21.4^{\mathrm{a}}$ & 0.3 \\
\hline & Kalahari Red & 14.0 & 18.5 & $19.2^{b}$ & 0.2 \\
\hline & Savanna & 16.3 & 22.7 & $19.5^{\mathrm{b}}$ & 0.2 \\
\hline
\end{tabular}

${ }_{1}$ Superscripts differ significantly for $P<0.001$. 
Table 4. Number of samples, effective number of alleles and expected and observed heterozygosity for the three breeds.

\begin{tabular}{lcccc}
\hline Breeds & $\begin{array}{c}\text { Mean n of } \\
\text { samples }\end{array}$ & $\mathrm{Ne}^{1}$ & $\begin{array}{c}\text { Unbiased Hz } \\
(\mathrm{SD})\end{array}$ & $\begin{array}{c}\text { Observed H } \\
(\mathrm{SD})\end{array}$ \\
\hline S A Boer goat & 31 & 2.9 & $0.57(0.19)$ & $0.54(0.22)$ \\
Boer goats EC $^{2}$ & 31 & 3.3 & $0.65(0.15)$ & $0.62(0.20)$ \\
Boer goat $^{3}$ & 17 & 3.1 & $0.62(0.17)$ & $0.66(0.35)$ \\
Kalahari-Red & 60 & 3.3 & $0.68(0.10)$ & $0.63(0.13)$ \\
Savanna & 55 & 3.4 & $0.69(0.10)$ & $0.61(0.08)$ \\
\hline
\end{tabular}

${ }^{1} \mathrm{Ne}=$ Effective number of alleles.

$2=$ Experimental population of Boer goats Eastern cape province.

$3=$ Experimental population of Boer goats Limpopo province.

values calculated for this study were all above $50 \%$ with the lowest value for the SA Boer goat (57\%) and a slight difference between the Savanna (68\%) and Kalahari Red (69\%) (Table 4). Both the experimental flocks of SA Boer goat had higher heterozygosity values than the commercial flocks of the Northern Cape Province.

In figure 5 the results of a Factorial Correspondence Analysis are shown with the assignment of the individual goats analysed into three groups.

\section{Discussion}

Goats have been largely neglected as an animal genetic resource in South Africa when compared to cattle and sheep. Despite a number of research initiatives undertaken over the past 40 years on goat production, there are still aspects that require attention and a need for effective coordination of research programs to lead to the successful conservation and utilization of goats. The South African Boer goat, Savanna and Kalahari Red goats have only recently been classified as distinct breeds, while their phenotypic and genetic characterization are still not well defined.

Both the Boer goat and Savanna breeds have established breeders associations while a breeders club was founded for the Kalahari Red goats with set breed standards (www.studbook.co.za/telers). The breed standards consist of primarily phenotypic descriptions, colour and culling defects. Attention is also given to type traits related to functional efficiency. Except for the colour variation between the three breeds, the breed standards are quite similar and the aim is to select for a well adapted, functionally efficient meat type goat breed.
Morphometric measurements recorded for this study (reported in table 3 ) indicate a larger within breed variation (minimum and maximum) than between the breeds. Statistical differences were observed between the Savanna and the other two breeds for depth and length but not $(P<0.001)$ for height. The only trait where significant differences were observed among all three breeds was for head width, where the Boer goat had the broadest head and the Savanna the narrowest. The Boer goat had the largest pelvis with and the longest ears compared to the other two breeds $(P<0.001)$. The differences in morphometric traits among the breeds are fairly insignificant and highlight the need for a genetic characterization to be able to distinguish the breeds accurately on a genotypic level and to ensure sufficient diversity within the breeds for long term conservation. The heterozygosity values estimated for the three breeds are relatively high and correspond with the observations for local South African breeds by Visser et al. (2004) and values reported in studies on goats by Martinez et al., 2006; Els et al., 2004; Li et al., 2002, but higher than those reported by Kumar et al, (2005) for Marwari goats. It is important to note that both the experimental populations of Boer goats not subjected to selection for improved performance had a higher genetic variation than the Boer goats sampled from the breeders (Table 4). The sample size of the goats sampled from the Limpopo flock was small and more samples need to be tested for further analyses. According to the Factorial Correspondence Analysis (Figure 5) the three breeds assign to three groups. The Kalahari Red goats can be distinguished as a group, while the SA Boer goat and Savanna tend to overlap. More samples of indigenous goat types and Angora mohair goats are currently being added for further analyses of genetic diversity and relatedness for a more detailed characterization of all South African goats. 
The meat goat breeds are often noted in literature as having adaptive characteristics in terms of heat tolerance and feeding behavior (Erasmus, 2000; Malan, 2000). There is an urgent need to investigate these traits to ensure conservation of the unique genetic resource. Shrestha and Fahmy (2005) reported that nearly 800 farm animal genetic resources have already been lost and about 30 percent of the remaining species are associated with some degree of risk. The FAO predicts that 20 percent of livestock breeds are at risk of extinction and more than half of these breeds are likely to be found in developing countries (FAO, 2007).

\section{Conclusion}

Goat meat production in South Africa is relatively low compared to beef and mutton, but it plays an important role in African cultural activities and is the preferred meat in certain communities (Webb et al., 2005). In addition to the local production, both SA Boer goat and Kalahari Red have been exported to Europe and the USA. It is important that breed standards for the locally developed breeds be revised and genetic analyses included to ensure that superior genetics will be conserved. Adaptive phenotypic characteristics of both the meat type breeds and indigenous types require further investigation for the long term conservation of goats as a unique animal genetic resource in South Africa.

\section{List References}

Belkhir, K., Borsa, P., Chikhi, L., Raufaste, N. \& Bonhomme F. 1996-2002. GENETIX 4.04, logiciel sous Windows TM pour la génétique des populations. Laboratoire Génome, Populations, Interactions, CNRS UMR 5000, Université de Montpellier II, Montpellier (France).

Campbell, Q. 1995. Indigenous goats. In: The Indigenous Sheep and Goat Breeds of South Africa. Eds. Campbell, Q., Dreyer printers and publishers, Bloemfontein, pp. 35-44.

Campbell, Q.P. 2003. The origin and description of southern Africa's indigenous goats. South African Journal of Animal Science, 4, 18-22.

Coetzee, R.J. 1998. Socio-economic aspects of sustainable goat production. In: Proceedings of the Workshop on Research and Training Strategies for
Goat Production Systems in South Africa, King's Lodge Hotel, Hogsback, Eastern Cape, South Africa, Ed. by Webb, E.C., Cronje, P.B., pp. 14-16.

Donkin, E.F., Ramsey, K.A. \& Van Marle-Köster, E. 2004. Unpublished. Department of Animal \& Wildlife Sciences, University of Pretoria, South Africa.

Els, J.F., Kotze, A. \& Swart, H. 2004. Genetic diversity of indigenous goats in Namibia using microsatellite markers: preliminary results. South African Journal Animal Science, 34, (Supplement 2) 65-67.

Erasmus, J.A. 2000. Adaptation to various environments and resistance to disease of the Improved Boergoat. Small Ruminant Research, 36, 179-187.

FAO. 2007. State of the World's Animal Genetic Resources for Foord and Agriculture. Rome 2007, <ftp://ftp.fao.org/docrep/fao/010/a1250e/ a1250e.pdf>.

Kumar, D., Dixit, S.P., Sharma, R., Pandey, A.K., Sirohi, G., Patel, A.K., Aggarwal, R.A.K., Verma, N.K., Gour, D.S. \& Ahlawat, S.P.S. 2005. Population structure, genetic variation and management of Marwari goats. Small Ruminant Research, 59, 41-48.

Li, M.H., Zhao, S.H. Bian, C., Wang, H.S., Wei, H., Liu, B., Yu, M., Fan, B., Chen, S.L., Zhu, M.J., Xiong, T.A. \& Li, K. 2002. Genetic relationships among twelve Chinese indigenous goat populations based on microsatellite analysis. Genetic and Sell Evolution. 34, 729-744.

Malan, S.W. 2000. The improved Boer goat. Small Ruminant Research, 36, 165-170.

Maree, C. \& Plug, I. 1993. Origin of Southern African Livestock and their potential role in the industry. In Livestock Production Systems. Casey \& Maree (Eds). Agri Development Foundation, Pretoria, South Africa. ISBN 0-620-17126.

Martinez, M.M., Acosta, J., Vega-Pa, J.L. \& Delgado, J.V. 2006. Analysis of the genetic structure of the canary goat populations using microsatellite. Livestock Science 102, 140-145.

Park, S.D.E. 2001. Trypanotolerance in West African cattle and the population genetic effects of Selection. Phd thesis University of Dublin. 
Pieters, A. 2007. Genetic characterization of commercial goat populations in South Africa. MSc (Agric) thesis. University of Pretoria, South Africa.

Sambraus, H.H. 1992. Goats. In: A Colour Atlas of Livestock Breeds. Eds. Sambraus, H.H. Wolfe Publishing, Germany. 137-156.

Shrestha, J.N.B. \& Fahmy, M.H. 2005. Breeding goats for meat production: a review 1. Genetic resources, management and breed evaluation. Small Rumin. Res., 58, 93-106.
Visser, C., Hefer, C.A., van Marle-Köster, E. \& Kotze, A. 2004. Genetic variation of three commercial and three indigenous goat populations in South Africa. S. Afr. J. Anim. Sci., 34

(supplement 1), 24-27.

Webb, E.C., Casey, N.H. \& Langa, L. 2005. Goat meat quality. Small Rum. Res., 60: 153-166.

Yeh, F.C., Yang, Rong-cai, \& Boyle, T. 1999. POPGENE VERSION 3.2. Centre for International Forestry research. University of Alberta. 


\title{
Genetic diversity and zebu genes introgression in cattle population along the coastal region of the Bight of Benin
}

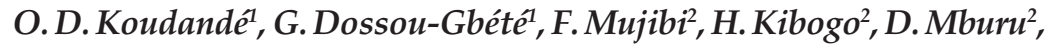 \\ G.A.Mensah ${ }^{1}$, O. Hanotte ${ }^{2} \mathcal{E}$ J.A.M.van Arendonk ${ }^{3}$ \\ ${ }^{1}$ Institut National des Recherches Agricoles du Bénin, 01 BP 884, Cotonou, Benin \\ ${ }^{2}$ International Livestock Research Institute, (ILRI) P. O. Box 30709, Nairobi, Kenya \\ ${ }^{3}$ Animal Breeding and Genetics Group, Wageningen Institute of Animal Sciences, Wageningen University, \\ P.O. Box 338, 6700 AH Wageningen, The Netherlands
}

\section{Summary}

Genetic diversity and Zebu genetic introgression have been assessed in five subpopulations of cattle along the coastal region of Togo, Benin and Nigeria using 15 autosomal and one $\mathrm{Y}$ - specific microsatellite markers. Mean observed heterozygosity $(\mathrm{Ho})$ ranges from 0.55 to 0.61 and the mean number of alleles (MNA) from 5.47 to 6.47. Genetic differentiation indexes $\left(\mathrm{F}_{\mathrm{st}}\right)$, were significant between the five subpopulations $(P<0.01)$. Some possible population diagnostic alleles are identified with allele 254 at locus ILSTS033 and allele 182 at locus ILSTS005 found only in the population from Togo with frequencies of $5.41 \%$ and $12.82 \%$ respectively. Allele 226 of locus ILSTS103 is fixed in the Togolese population (100\%) and almost fixed $(98.75 \%)$ in the Benin-Valley population. Y chromosome analysis reveals male Zebu introgression in all five populations with a frequency of indicine $Y$ chromosome ranging from $37.5 \%$ in Benin-Valley and Benin Plateau East to $100 \%$ for Benin Plateau West. Admixture analysis using the programme STRUCTURE $(\mathrm{k}=2)$ confirms phenotypic observations suggesting different level of taurine background and therefore Zebu introgression amongst the populations. Within populations, variations in levels of Zebu admixture between herds were also detected. Whereas the valley population from Benin shows low level of Zebu introgression, it is the population from Benin Plateau East which is the purest.

\section{Résumé}

La diversité génétique et l'introgression de gènes de zébu dans la population de bovins le long de la côte du golfe de Guinée allant du Togo au Nigeria ont été évaluées à partir de 15 marqueurs microsatellites autosomes et un marqueur spécifique du chromosome Y. La moyenne des hétérozygotes Ho varie de 0,55 à 0,61 et le nombre moyen d'allèles (NMA) de 5,47 à 6,47. Les indices de différenciation génétique $\left(\mathrm{F}_{\mathrm{st}}\right)$ sont différents entre les cinq sous populations $(P<0,01)$. Des allèles spécifiques de population sont identifiés aux loci ILSTS033 (allèle 254) et ILSTS005 (allèle 182) dans la sous population du Togo avec des fréquences respectives de 5,41 et $12,82 \%$. L'allèle 226 du locus ILSTS103 est totalement $(100 \%)$ fixé dans la sous population togolaise et presque $(98,75 \%)$ dans la sous population de la vallée au Bénin. L'évaluation du marqueur spécifique du chromosome Y révèle l'introgression de gènes de zébu dans les cinq sous populations allant de 37,5\% dans la vallée du Bénin et sur le Plateau Est à 100\% sur le Plateau Ouest. L'analyse de mélange utilisant le programme STRUCTURE $(\mathrm{k}=2)$ confirme les observations phénotypiques concluant à l'introgression de gènes de zébu au sein des populations. Des variations de mélange sont observées entre troupeaux au sein d'une même sous population. Alors que les animaux dans la vallée au Bénin présentent un niveau faible d'introgression de gènes de zébu, $c^{\prime}$ est la sous population du Plateau Est qui paraît être la plus pure.

\section{Resumen}

La diversidad genética y la introgresión de genes de zebú en la población de bovinos a lo largo de la costa del golfo de Guinea que va desde Togo hasta Nigeria han sido evaluados a partir de 15 marcadores microsatelitares autosomos y un marcador específico del cromosoma Y. La media de heterocigosis Ho varía de 0,55 a 0,61 y el número medio de alelos (NMA) de 5,47 a 6,47. Los índices de diferenciación genética $\left(\mathrm{F}_{\mathrm{st}}\right)$ son diferentes entre 
las cinco sub-poblaciones $(P<0,01)$. Han sido identificados alelos específicos de poblaciones en los loci ILSTS033 (alelo 254) e ILSTS005 (alelo 182) en la sub-población del Togo con frecuencias respectivas de 5,41 y $12,82 \%$. El alelo 226 del locus ILSTS103 está totalmente fijado $(100 \%)$ en la sub-población togolesa y casi $(98,75 \%)$ en la sub-población del valle del Benín. La evaluación del marcador específico del cromosoma Y revela la introgresión de genes de zebú en las cinco sub-poblaciones que van de $37,5 \%$ en el valle del Benín y en la Meseta Este, hasta 100\% en la Meseta Oeste. El análisis de mezcla utilizando el programa STRUCTURE ( $k=2$ ) confirma las observaciones fenotípicas que indican la introgresión de genes de zebú en el interior de las poblaciones. Variaciones de mezclas han sido observadas entre rebaños al interior de una misma población. Mientras que los animales del valle del Benín presentan un nivel de introgresión de genes de zebú bajo, la sub-población de la Meseta Este parece ser la más pura.

Key words: Cattle, Microsatellites, Genetic diversity, Zebu genes introgression.

\section{Introduction}

West African taurine cattle (B. taurus) breeds are under threat of extinction due to uncontrolled breeding practices by farmers aiming to enhance the size and the productivity of their animals. However, it is recognised that animals of these breeds are well adapted to their local environments and remain productive in areas where Zebu or crossbreeds are often unable to survive (Agyemang et al. 1991; Uza, 1997). The phenotypic traits of these animals are the result of hundreds of years of natural selection in relation to the local environments under permanent tsetse, ticks and helminth challenge. It is clear that uncontrolled crossbreeding with exotic breeds poses a threat to the adaptive traits of this unique animal genetic resource. This uncontrolled crossbreeding is the result of poor agricultural policies with no long term breeding goals, each farmer developing his own objective with emphasis on short-term results.

In the early eighties, the Food and Agriculture Organisation of the United Nations started alerting public opinion on the subject of animal genetic resources conservation and management (FAO, 1981). At the Earth Summit in 1992 in Rio de Janeiro, 157 countries signed the United Nations convention on biological diversity and subsequently FAO (1992) launched a special program for the global management of farm animal genetic resources. The aim of this program is to maintain in each species a maximum genetic diversity of the gene pool to allow for future unforeseen needs in the development of sustainable animal production systems. In addition the program aims at prompt actions to preserve animal breeds at risk of extinction.

Studies in the last decade have shown that African cattle were most likely domesticated within the African continent, separately from the other centres of domestication in the Fertile Crescent and in the Indian sub-continent, from the wild African auroch B. primigenius (Bradley et al., 1996). Their separate origin indicates that they represent a unique set of genetic characteristics. Today, the remaining pure African taurine cattle are only found within the West African taurine cattle living in tsetse-infected areas. These populations, given their origins and their adaptation to local environmental conditions (e.g. disease resistance), represent a unique genetic resource.

Introgression with Zebu cattle in West African taurine cattle populations, however, is common (MacHugh et al., 1997; Hanotte et al., 2000) and is diluting progressively the African taurine genetic background of these breeds. Ultimately, this introgression will result in the loss of the unique genetic adaptation of these breeds. Currently, the extent and pattern of Zebu introgression into the indigenous taurine populations is well described by Hanotte et al. (2002). This study, however, did not include the Lagune breed. The current paper is therefore a complementary study to that of Hanotte et al. (2002), targeting the Lagune breed in the Bight of Benin. Results of this study can be used to identify suitable pure West African taurine populations for their inclusion in breeding programs that aim at conserving and utilising these unique indigenous genetic resources. These results could also be the starting point for the implementation of a sustainable breeding programme for livestock production in that region.

\section{Material and Methods}

\section{Sampling}

Blood samples were collected from different cattle subpopulations in Benin, Nigeria and Togo. Forty animals, of which eight were males, were sampled for each identified subpopulation. Three subpopulations have been sampled in Benin, which are Benin Plateau West (BPW), Benin Valley (BV) 
and Benin Plateau East (BPE). Two neighbouring regions of the target area in Benin have been considered (Figure 1) in Nigeria (NG) and Togo (TG) resulting in a maximum of 200 sampled cattle.

Appropriate materials such as Wattman filter paper, evacuated blood collection tubes $(5 \mathrm{ml})$ and Eppendorf tubes for stocking buffy coats were used for handling samples. Blood samples were collected from each animal in two evacuated blood collection tubes containing 3.2\% EDTA and the buffy coat (white cells) was taken after spinning the tubes at $2400 \mathrm{rpm}$ at ambient temperature. Collected buffy coats were added with $8 \mathrm{M}$ urea solution and kept at ambient temperature. To be on the safe side, blood samples were also collected on Wattman paper and dried at $40^{\circ} \mathrm{C}$ in oven, then stored at ambient temperature. Sampling included as many animals from different herds as possible to avoid direct relationship between sampled individuals. In other terms, one male and four females were sampled per herd and a total of eight herds were visited for each identified subpopulation. All samples were conveyed to the laboratory of genetics at ILRI campus in Nairobi (Kenya) for processing.

\section{Laboratory procedures}

DNA was extracted from the buffy coats with standard procedures as described by Sambrook et al. (1999). Sixteen markers, of which one was on the $Y$ chromosome, were used for genotyping. They were TGLA126, TGLA122, ILSTS033, ILSTS013, ILSTS008, ILSTS005, ILSTS006, ILSTS036, ILSTS028, ILSTS023, ILSTS103, ETH152, BM2113, BM1824, AGLA293 and INRA124. Polymerase Chain Reaction (PCR) for amplification of microsatellite loci were performed as described in Hirano et al. (1996) and Kemp et al. (1995).

Genotyping and gel analysis were performed using automatic DNA sequencer ABI 377 and associated analysis software Genescan ${ }^{\mathrm{TM}}$

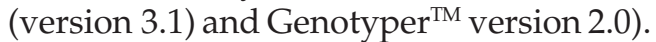

\section{Data analysis}

Marker allele frequencies have been analysed using the Microsatellite toolkit program (Park, 2001). The genetic diversity of each population was evaluated by computing the mean number of alleles per locus (MNA), the observed heterozygosity $\left(\mathrm{H}_{\mathrm{obs}}\right)$, and the expected heterozygosity $\left(\mathrm{H}_{\mathrm{exp}}\right)$ using the microsatellite toolkit (Park, 2001) as well as GENEPOP, version 3.3 (Raymond and Rousset, 1995). Subpopulations have been checked for HWE using the exact probability test with GENEPOP. The level of genetic differentiation among populations was examined using $F$-statistics (Weir and Cockerham, 1984). Genetic distances between populations $\mathrm{D}_{\mathrm{A}}$ (Nei et al., 1983) were calculated and used to construct a phylogenetic tree

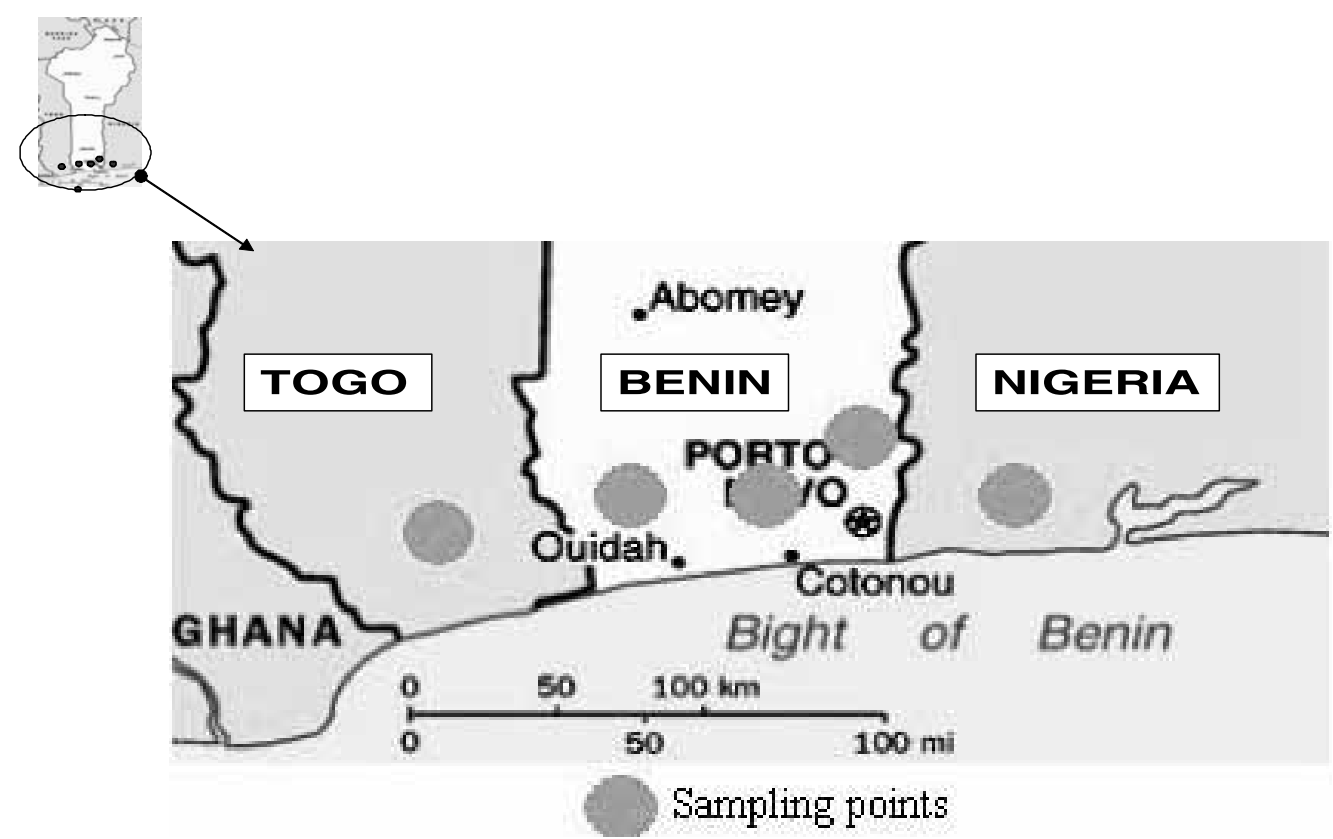

Figure 1.Benin map showing the sampled populations locations. 
with the neighbour joining algorithm (Saitou and Nei, 1987). The level of Zebu introgression was estimated with the programme STRUCTURE using the ADMIX 1.0 software (Bertorelle and Excoffier, 1998). Correlations between phenotype and populations structure results were performed using Microsoft Excel.

\section{Results}

\section{Genetic variation}

From the five subpopulations under study here, 130 alleles were found for all 15 autosomal marker loci that have been genotyped over the 200 sampled animals (Table 1). The total number of alleles detected per locus ranged from 4 to 16 resulting in a mean number of alleles (MNA) per locus of 8.67.

The number of alleles summed over the 15 loci per subpopulation ranged from 82 in BPE to 97 in TG (Table 1) giving a MNA per locus for each subpopulation varying from 5.47 to 6.47 (Table 2). These variations are not strong enough $(P>0.05)$ to differentiate current subpopulations. However, allele 254 of the locus ILSTS_033 and allele 182 of ILSTS_005 are found solely in TG with a frequency of $5.41 \%$ and $12.82 \%$ respectively. Alleles 171 and 175 of ILSTS_023 are equally distributed (50\%) within TG and BV subpopulations. Further, allele 226 of locus ILSTS_103 is fixed in TG (100\%) whereas it is almost (98.75\%) fixed in BV.

The expected heterozygosity computed over the 15 loci for each of the five subpopulations ranged from 0.593 (BV) to 0.673 (BPW) whereas the observed heterozygosity varied from 0.55 in BPE to 0.61 in BPW (Table 2).

None of the subpopulations deviated from HWE through all loci at 5 p. cent level. Out of the 15 loci under study, only loci ILSTS006 $(P<0.006)$, ILSTS023 $(P<0.005)$ and ILSTS103 $(P<0.05)$ deviated consistently from HWE for all five subpopulations (Table 3). Except those three loci, TG deviated $(P<0.05)$ from equilibrium at two loci (BM1824, BM2113), BPW at four loci (TGLA126, ILSTS033, ILSTS008, BM2113), BV at two loci (ILSTS008, ILSTS033), BPE at three loci (ILSTS033, ILSTS036, BM2113), and NG at two loci (ILSTS013, ILSTS036).

\section{Genetic distances and breed relationships}

Table 4 summarizes genetic distances and gene differentiation indices between all pairs of subpopulations. The largest genetic distance (0.1183) was obtained between TG and BPE, whereas the smallest (0.0666) was obtained between

Table 1. Total number of alleles per locus and per subpopulation.

\begin{tabular}{lcccccc}
\hline & & \multicolumn{5}{c}{ Benin } \\
Locus & Togo & BPW & BV & BPE & Nigeria & Total \\
\hline TGLA126 & 7 & 7 & 6 & 6 & 6 & 7 \\
TGLA122 & 8 & 8 & 9 & 7 & 8 & 11 \\
ILSTS033 & 7 & 5 & 4 & 7 & 6 & 9 \\
ILSTS013 & 4 & 4 & 4 & 4 & 4 & 4 \\
ILSTS008 & 4 & 5 & 4 & 3 & 3 & 5 \\
ILSTS005 & 5 & 4 & 3 & 4 & 3 & 5 \\
ILSTS006 & 8 & 5 & 8 & 5 & 5 & 9 \\
ILSTS036 & 12 & 8 & 9 & 8 & 9 & 16 \\
ILSTS028 & 6 & 8 & 6 & 6 & 7 & 10 \\
ILSTS023 & 2 & 5 & 2 & 4 & 5 & 6 \\
ILSTS103 & 1 & 5 & 2 & 4 & 5 & 7 \\
ETH152 & 6 & 5 & 7 & 5 & 5 & 8 \\
BM2113 & 12 & 10 & 7 & 6 & 9 & 12 \\
BM1824 & 6 & 4 & 4 & 4 & 4 & 6 \\
AGLA293 & 9 & 8 & 12 & 9 & 8 & 15 \\
Total & 97 & 91 & 87 & 82 & 87 & 130 \\
\hline
\end{tabular}


Table 2. Comparison of genetic variability of five populations of cattle along the coastal region of Togo, Benin and Nigeria.

\begin{tabular}{lccc}
\hline Populations & 1 MNA $( \pm$ SE $)$ & ${ }^{2} \mathrm{H}_{\text {obs }}( \pm$ SE $)$ & $3 \mathrm{H}_{\exp }( \pm$ SE $)$ \\
\hline Togo & $6.47( \pm 3.14)$ & $0.5905( \pm 0.0202)$ & $0.6410( \pm 0.0539)$ \\
Benin Plateau West & $6.07( \pm 1.91)$ & $0.6083( \pm 0.0200)$ & $0.6725( \pm 0.0322)$ \\
Benin Valley & $5.80( \pm 2.88)$ & $0.5604( \pm 0.0204)$ & $0.5930( \pm 0.0503)$ \\
Benin Plateau East & $5.47( \pm 1.73)$ & $0.5504( \pm 0.0204)$ & $0.6194( \pm 0.0296)$ \\
Nigeria & $5.80( \pm 2.01)$ & $0.5603( \pm 0.0203)$ & $0.6338( \pm 0.0383)$ \\
\hline
\end{tabular}

${ }^{1}$ Mean number of alleles per locus.

${ }^{2}$ Observed heterozygosity.

${ }^{3}$ Expected heterozygosity.

Table 3. Hardy-Weinberg exact probability test by population.

\begin{tabular}{|c|c|c|c|c|c|}
\hline \multirow[b]{2}{*}{ Locus } & \multirow[b]{2}{*}{ Togo } & \multicolumn{3}{|c|}{ Benin } & \multirow[b]{2}{*}{ Nigeria } \\
\hline & & $\mathrm{BPW}$ & $\mathrm{BV}$ & $\mathrm{BPE}$ & \\
\hline TGLA126 & $0.1266(0.0094)$ & $0.0324(0.0058)$ & $0.9689(0.0032)$ & $0.3372(0.0138)$ & $0.1626(0.0086)$ \\
\hline TGLA122 & $0.0918(0.0143)$ & $0.1416(0.0109)$ & $0.5619(0.0241)$ & $0.3201(0.0204)$ & $0.2617(0.0191)$ \\
\hline ILSTS033 & $0.0122(0.0035)$ & $0.0000(0.0000)$ & $0.0302(0.0026)$ & $0.0018(0.0009)$ & $0.2594(0.0157)$ \\
\hline ILSTS013 & $0.3394(0.0082)$ & $0.2777(0.0082)$ & $0.9153(0.0024)$ & 0.5509 (0.0065) & $0.0219(0.0018)$ \\
\hline ILSTS008 & $0.3769(0.0107)$ & $0.0052(0.0014)$ & $0.0024(0.0007)$ & $0.0842(0.0049)$ & $0.8024(0.0036)$ \\
\hline ILSTS005 & $0.1651(0.0080)$ & $0.0052(0.0071)$ & $0.3149(0.0082)$ & $0.7353(0.0076)$ & $0.6628(0.0049)$ \\
\hline ILSTS006 & $0.0000(0.0000)$ & $0.0000(0.0000)$ & $0.0000(0.0000)$ & 0.0057 (0.0018) & $0.0000(0.0000)$ \\
\hline ILSTS036 & $0.0797(0.0167)$ & $0.1021(0.0100)$ & $0.1006(0.0160)$ & $0.0294(0.0053)$ & $0.0001(0.0001)$ \\
\hline ILSTS028 & $0.0805(0.0088)$ & $0.1186(0.0129)$ & $0.2908(0.0173)$ & $0.2782(0.0152)$ & $0.3055(0.0202)$ \\
\hline ILSTS023 & $0.0000(0.0000)$ & $0.0001(0.0001)$ & $0.0000(0.0000)$ & $0.0000(0.0000)$ & $0.0000(0.0000)$ \\
\hline ILSTS103 & - & $0.0003(0.0003)$ & - & $0.0000(0.0000)$ & $0.0183(0.0035)$ \\
\hline ETH152 & $0.0672(0.0065)$ & $0.4927(0.0091)$ & $0.3976(0.0174)$ & $0.9354(0.0049)$ & $0.3382(0.0115)$ \\
\hline BM2113 & $0.0396(0.0076)$ & $0.0110(0.0028)$ & $0.2903(0.0158)$ & 0.0089 (0.0016) & $0.3507(0.0163)$ \\
\hline BM1824 & $0.0414(0.0064)$ & $0.9355(0.0020)$ & $1.0000(0.0000)$ & $0.8824(0.0045)$ & $0.0616(0.0055)$ \\
\hline AGLA293 & $0.5448(0.0222)$ & $0.6256(0.0170)$ & $0.2169(0.0274)$ & $0.0676(0.0097)$ & $0.0907(0.0103)$ \\
\hline
\end{tabular}

NG and BPW. This result is in contrast to what would be expected given the geographic location of these subpopulations (Figure 1). The smallest coefficient of differentiation was obtained between TG and BPW, and the highest was between TG and $\mathrm{BPE}$ which is in agreement with the largest genetic distance obtained. The F-statistics results showed that the five populations were significantly different from each other $(P=0.0001)$. Estimates of $\mathrm{F}_{\mathrm{ST}}$ for each locus and for each population pair are summarized in Table 5.

The neighbour-joining tree based on genetic distance $\mathrm{D}_{\mathrm{A}}$ is represented in figure 2 . It shows the existing relationships among the five subpopulations according to studied loci. As it would be expected, BV and BPE are close subpopulations as shown in this figure.

\section{Population structure (admixture)}

Genetic admixture analysis shows that all five subpopulations are introgressed with Zebu genes but to different degrees (Figure 3), whereas subpopulations from TG and BPW harbour high levels of introgression at 0.753 and 0.651 , respectively. BPE is the least introgressed with introgression coefficients equal to 0.188 . BV and NG have intermediate coefficient, 0.309 and 0.390 , respectively. On individual basis, the level of 
Table 4. Genetic distance between five cattle subpopulations along the coastal region of Togo, Benin and Nigeria calculated using $D_{A}$ (Nei et al., 1983) below diagonal and Weir and Cockerham (1984) $F_{S T}$ above the diagonal.

\begin{tabular}{lccccc}
\hline & \multicolumn{3}{c}{ Benin Plateau } & \multicolumn{3}{c}{ Benin Plateau } \\
& Togo & West & Benin Valley & East & Nigeria \\
\hline Togo & - & 0.0205 & 0.0341 & 0.0564 & 0.0493 \\
Benin & 0.0795 & - & 0.0349 & 0.0310 & 0.0258 \\
$\begin{array}{l}\text { Plateau West } \\
\text { Benin Valley }\end{array}$ & 0.0866 & 0.0917 & - & & \\
Benin & 0.1183 & 0.0740 & 0.0809 & -0335 & 0.0463 \\
$\begin{array}{l}\text { Plateau East } \\
\text { Nigeria }\end{array}$ & 0.1103 & 0.0666 & 0.0914 & 0.0688 & 0.0377 \\
\hline
\end{tabular}

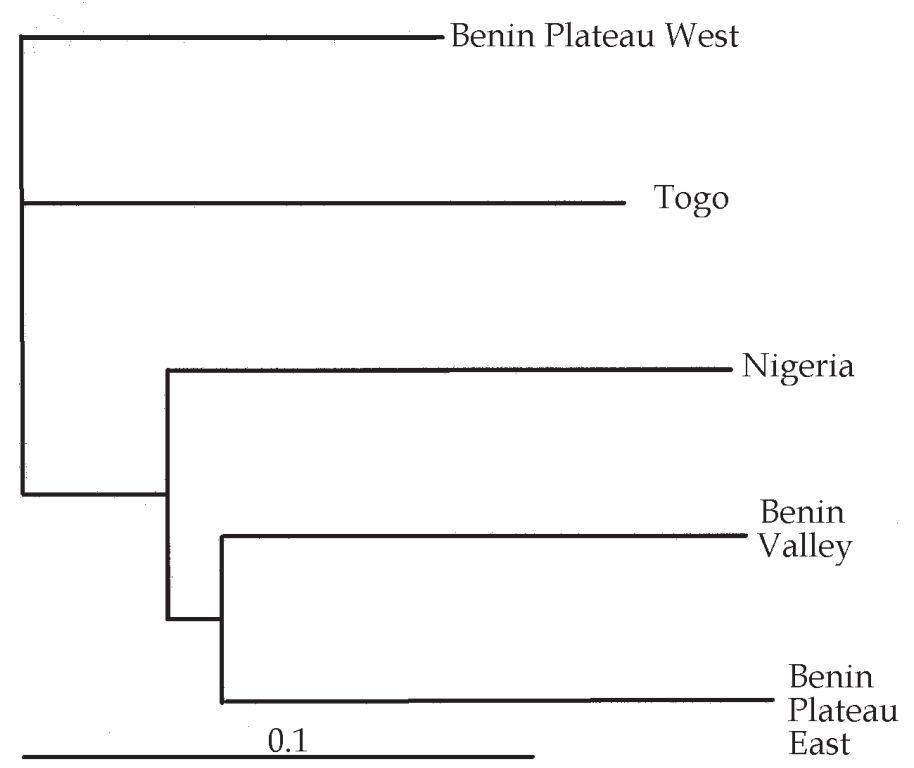

Figure 2. Neighbor joining dendogram showing the genetic relationship among the five sampled subpopulations along the coastal region from Togo to Nigeria.

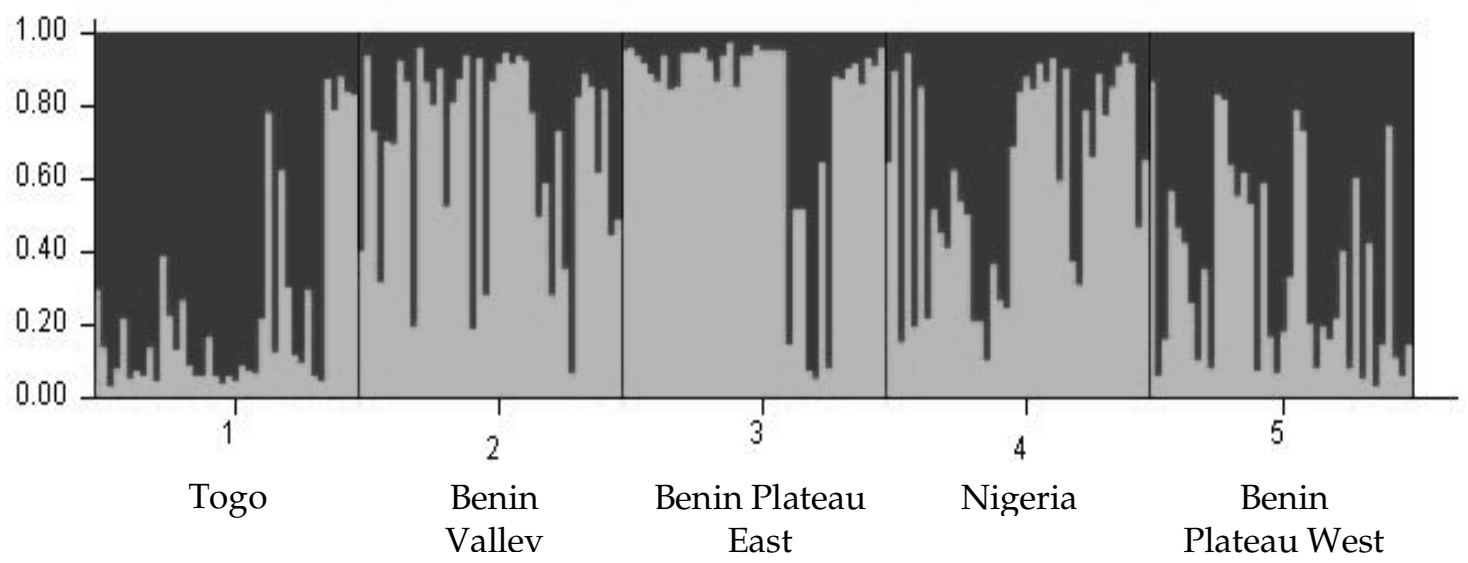

Figure 3. Admixture analysis showing zebu introgression in sampled subpopulations. 


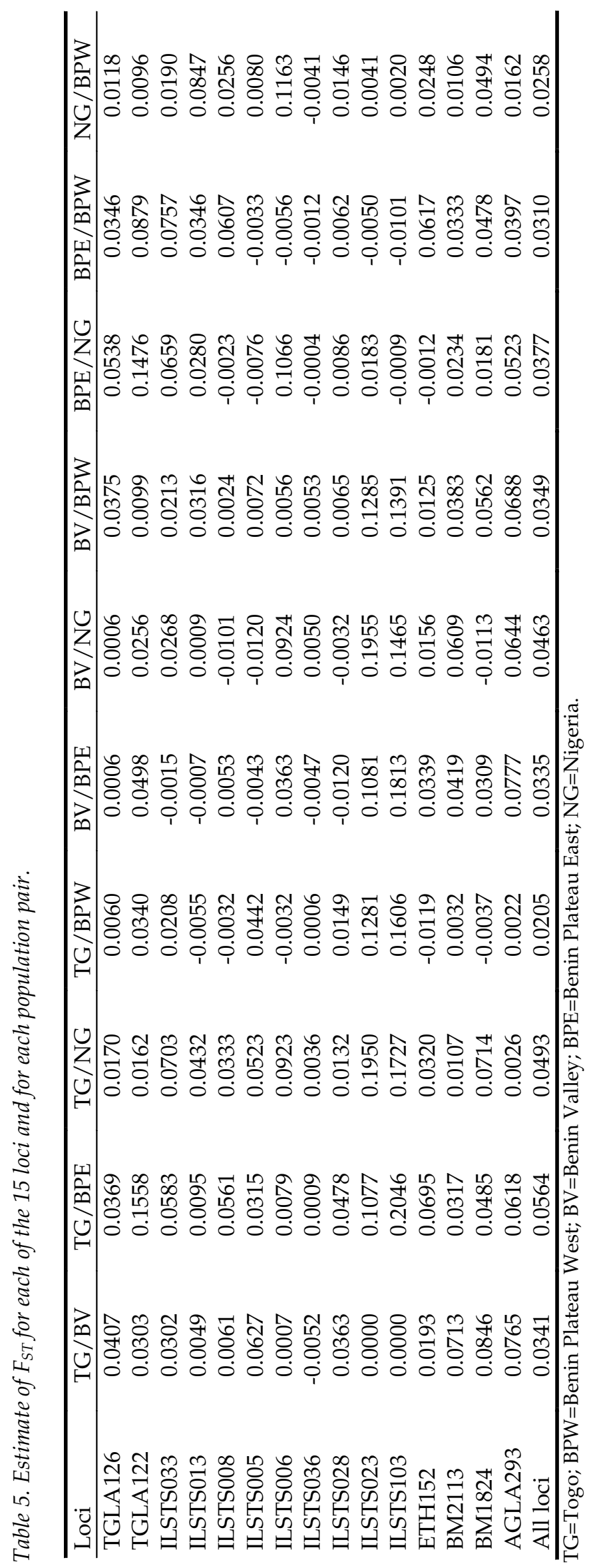




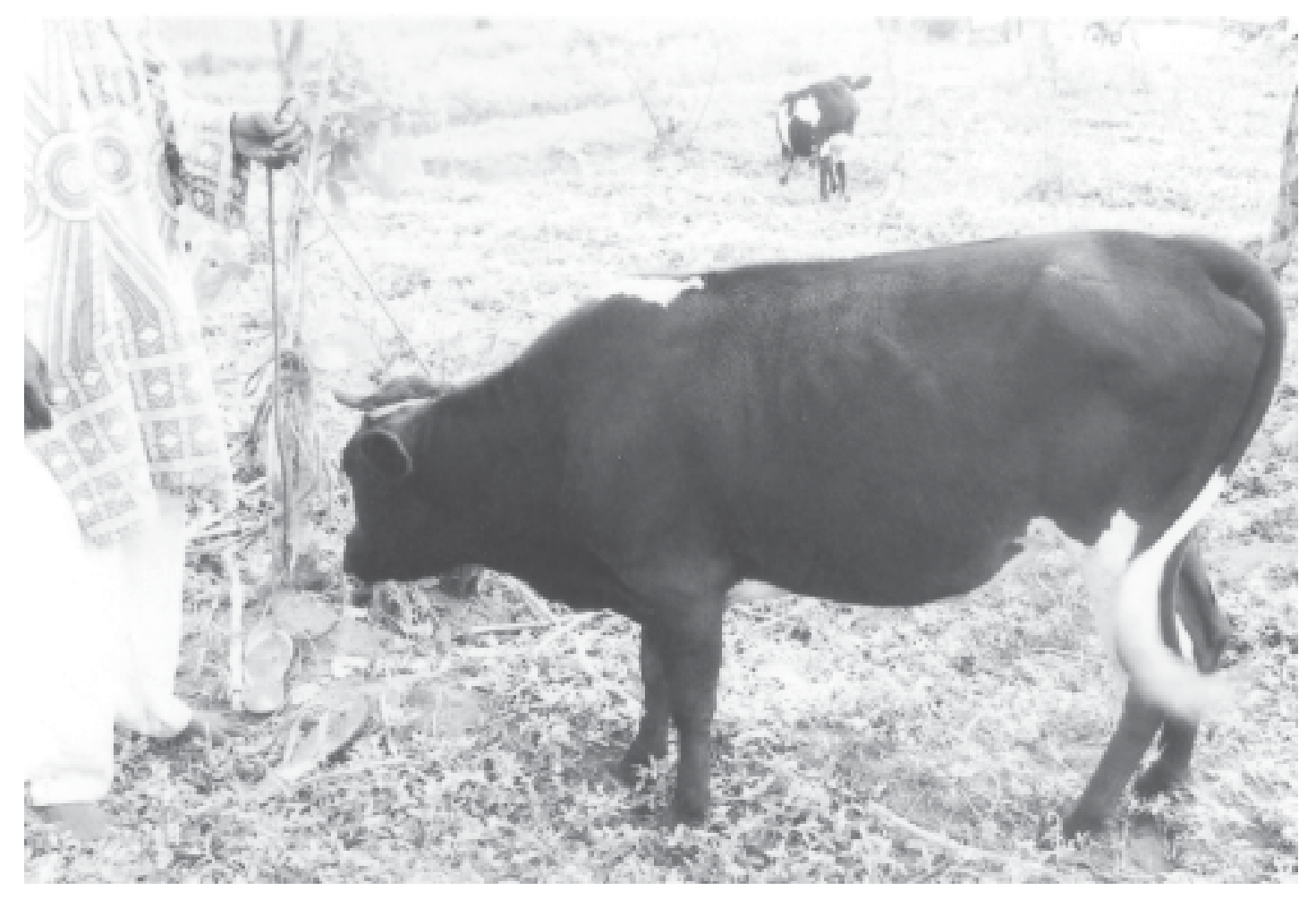

Figure 4. Typical Lagune cattle from Benin Plateau East (height is $81 \mathrm{~cm}$; girth circumference is $112 \mathrm{~cm}$ ).

Zebu introgression varies from 0.028 in TG to 0.967 in BPE.

Analysis of the $Y$ chromosome reveals male Zebu introgression in males of all five subpopulations with a frequency of indicine $Y$ chromosome ranging from $37.5 \%$ in $\mathrm{BV}$ and BPE to $100 \%$ for BPW. TG and NG have respectively 87.5 and $62.5 \%$. The correlation coefficient between the admixture results and those of the $Y$ chromosome analysis is 0.93 .

\section{Discussion}

With the upgrade breeding performed by livestock producers along the coastal regions of the three countries involved in this study, the observed variation between populations was expected. Indeed, looking for taller animals, mainly for market purposes, Borgou breed and Zebu have been introduced in diverse herds (Figure 5) resulting in the higher MNA for these populations. This is the case in TG and BPW (Table 2). This result is supported by the admixture analysis which gives the higher proportion of Zebu genes to subpopulations TG and BPW. In contrast, the subpopulation BPE has the least genetic variation in terms of MNA associated with a low heterozygosity. The low genetic variation in this subpopulation could be explained by the higher level of inbreeding in this subpopulation. This explanation is supported by the management system of these animals. Farmers used to keep their animals under their own habitat during night, then they are tethered to trees and moved from time to time to access forage. Bulls are owned by few people that hire them to non-owners for breeding. This means that breeding is under control, so as to ensure these animals are kept as pure as possible for their use in certain ritual ceremonies and as a dowry. Subpopulations TG and BV, however, have in common some alleles, that is allele 171 and 175 from ILSTSO23 at $50 \%$, allele 226 of locus ILSTS103 at the rate of $100 \%$ for the former and $98.75 \%$ for the latter. This result is surprising given that they are separated by subpopulation BPW which has lower frequency for these alleles (results not shown).

Genetic distances between pairs of subpopulations, coefficients of differentiation and 

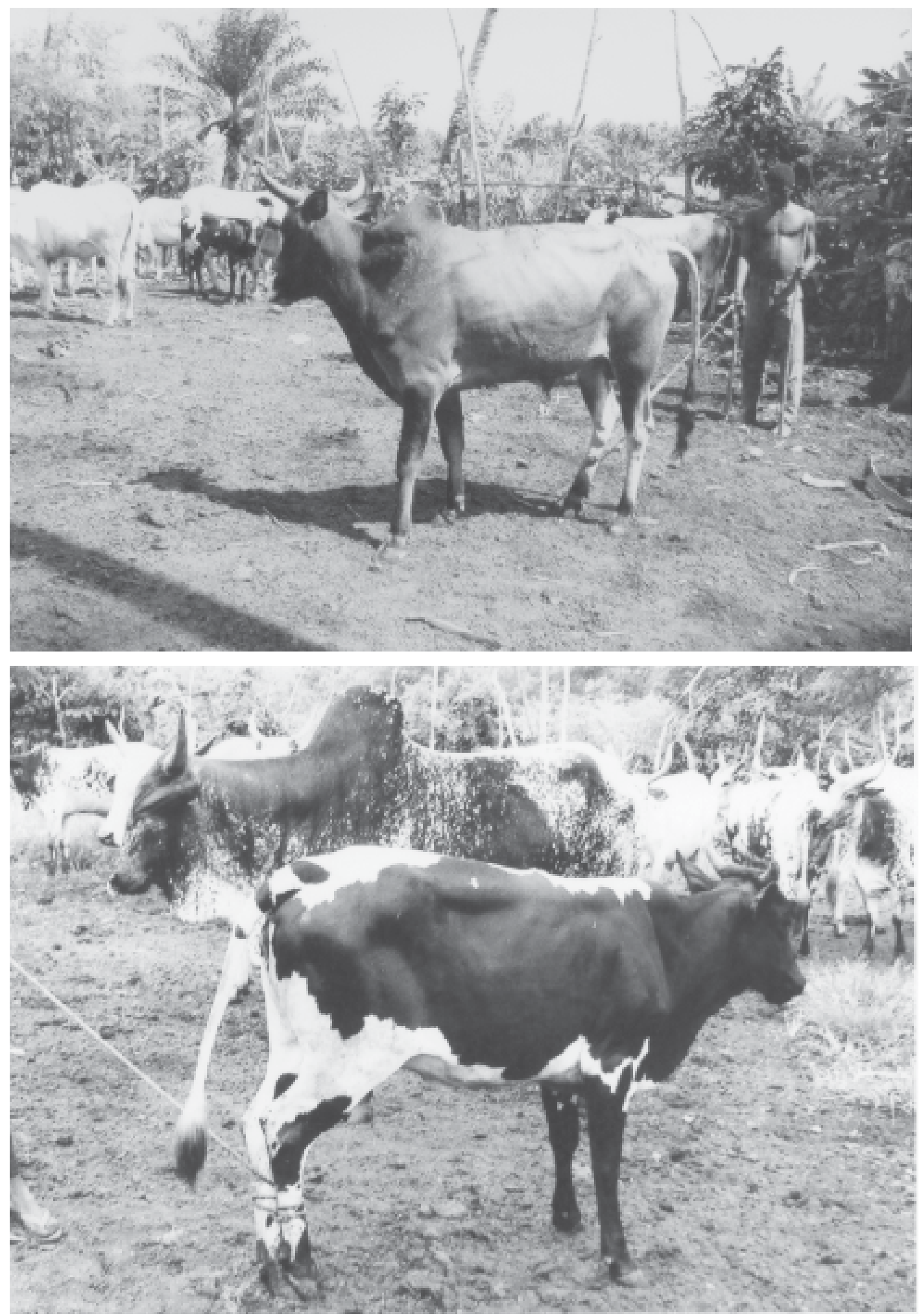

Figure 5. Zebu breeds that have been introduced in herds in the coastal regions. 
$\mathrm{F}_{\mathrm{ST}}$ confirm that the five subpopulations are different, although some results showed patterns that were not expected. We would expect the largest genetic distance to be between TG and BPE on one side and between NG and BPW on the other. The latter showed the least distance which is in contrast to what would be expected given the geographic location of these subpopulations (Figure 1). According to the admixture analysis, TG and NG showing the highest introgression of Zebu genes would be closer - that is not the case in current results. This could be explained by different sources of gene pools that have been used to perform the introgression. The existing relationships among subpopulations through the neighbour-joining tree clearly show that BV and $\mathrm{BPE}$ are close subpopulations as one could predict from figure 1.

Concurrently to blood sampling, height at wither and girth circumference were measured to relate the phenotype with genotype. There is quite an agreement between the results of the admixture model analysis and the phenotype of animals (correlation coefficient equals to 0.59 ), that is the higher the percent of Zebu genes, the higher is the height at wither. The availability of data on control animals (pure Zebu and pure Lagune) would have better strengthened current results.

The hypothesis that animals in the valley would be less introgressed by Zebu is true, but the population of Benin Plateau East is even purer than the one targeted in our study.

\section{Conservation futures}

The major objective of this study was to determine the level of Zebu introgression within cattle populations along the coastal regions of the Bight of Benin. This region is known to originally be the cradle of the Lagune cattle breed (Figure 4), animals of small size with a wither height varying from 90 to $100 \mathrm{~cm}$ and a heart girth from 130 to $137 \mathrm{~cm}$. As this study has demonstrated, there is a high tendency for Zebu or other breeds to be introgressed in this breed. Some herds and to some extent at least two populations, have been shown to be less polluted with Zebu blood. Throughout this study we placed an emphasis on naming cattle populations instead of breeds given the extent of crossbreeding, and current results support this point of view.

The hypothesis of the current study was to encounter cattle with low level of Zebu introgression that could be used for genetic resources conservation and it was expected to meet those animals in BV. Results of this study have shown that the purest taurine cattle were instead located in BPE. If such a conservation programme was to be undertaken, we would advise on the use of animals from BPE.

The status of BPE animals is the result of the breeding system in force in this area and for which objectives are clearly defined at the farmers' level. Therefore a sustainable way of handling the market for these animals remains to be identified. Indeed, there should be a strong marketing study that could identify market problems and define likely solutions. There should also be a sensitisation programme to make stakeholders be aware of different changes that might intervene. A contest and show program with good prizes could be a way of attracting farmers in that region to recognise the effort they are deploying on this breed. Any breeding programme, whatever is its goal, should integrate the indigenous knowledge and use of these animals. Throughout these actions, studies of the biochemical as well as the culinary quality of meat and milk produced from these animals should be undertaken to support the promotion of this breed.

\section{Acknowledgements}

The authors are grateful to WOTRO who have sponsored this post-doc project. They are thankful to Dr Sonhaye Séibou Adow, Director of the livestock department in TOGO and his staff, to Prof. Olusanya Olutogun, Drs Olatunji T.F. and Abdur R. Adbullah from Nigeria who have been very helpful in the sampling phase.

\section{List of References}

Agyemang, K., R.H. Dwinger, A.S. Grieve \& M.L. Bah. 1991. Milk production characteristics and productivity of N'Dama cattle kept under village management in the Gambia. J. Dairy Sci. 74, 1599-1608.

$$
\text { Bradley, D.G., D.E. MacHugh, }
$$

P. Cunningham \& R.T. Loftus. 1996. Mitochondrial diversity and the origins of African and European cattle. Proc. Natl. Acad. Sci USA 93, 5131-5135.

Bertorelle, G. \& L. Excoffier. 1998. Inferring admixture proportions from molecular data. Mol. Biol. Evol. 15, 1298 -1311. 
FAO. 1981. Animal genetic resources conservation and management. Proceedings of the FAO/UNEP technical consultation. FAO Animal Production and Health paper 24. FAO, Rome, pp. 388.

FAO. 1992. The management of global animal genetic resources. FAO Animal Production and Health paper 104. FAO, Rome, pp. 309.

Hanotte, O., C.L. Tawah, D.G. Bradley, M. Okomo, Y. Verjee, J. Ochieng \& J.E.O. Rege. 2000. Geographic distribution and frequency of a taurine Bos taurus and an indicine Bos indicus Y specific allele amongst sub-Saharan African cattle breeds. Molecular Ecology 9, 387-396.

Hanotte, O., D.G. Bradley, J.W. Ochieng, Y. Verjee, E.W. Hill \& J.E.O. Rege. 2002. African pastoralism: genetic imprints of origins and migrations. Science 296, 336-339.

Hirano, T., S. Nakane, K. Mizoshita, H. Yamakuchi, M. Inoue-Murajama, T. Watanabe, W. Barendse \& Y. Sugimoto. 1996.

Characterization of 42 highly polymorphic bovine microsatellite markers. Anim. Genet. 27, 365-368.

Kemp, S.J., O. Hishida, J. Wambugu, A. Rink, M.L. Longeri, R.Z. Ma, Y. Da, H.A. Lewin, W. Barendse \& A.J. Teale. 1995. A panel of polymorphic bovine, ovine and caprine microsatellite markers. Anim. Genet. 26, 299-306.

MacHugh, D.E., M.D. Shriver, R.T. Loftus, P. Cunningham \& D.G. Bradley. 1997.

Micorsatellite DNA variation and the evolution, domestication and phylogeography of taurine and zebu (Bos taurus and Bos indicus). Genetics 146, 1071-1086.

Nei, M., F. Tajima \& Y. Tateno. 1983. Accuracy of estimated phylogenetic trees from molecular data. J. Mol. Evolution 19, 153-170.

Park, S.D.E. (Ed.). 2001. Trypanotolerance in West African cattle taurine and the population genetic effects of selection. PhD thesis, University of Dublin, Ireland.

Raymond, M. \& F. Rousset. 1995. GENEPOP (version 1.2): population genetics software for exact tests and ecumenicism. J. Heredity 86, 248-249.

Saitou, N. \& M. Nei. 1987. The neighbor-joining method: a new method for reconstructing phylogenetic trees. Molecular Biology and Evolution 4, 406-425.

Sambrook, J., E.F. Fritsch \& T. Maniatis. 1989. Molecular Cloning: A Laboratory manual. $2^{\text {nd }}$ edition, Cold Spring Harbor Laboratory Press, New York.

Uza, D.V. 1997. The productivity of Muturu cattle (Bos brachyceros) under ranching conditions in the Southern Guinea Savanna of Benue state, Nigeria. Outlook on Agriculture 26, 19-23.

Weir, B.S. \& C.C. Cockerham. 1984.

Estimating F-statistics for the analysis of population structure. Evolution 38, 1358-1370. 